\title{
REVIEWING STUDIES ON CLIMATE CHANGE AWARENESS IN VIETNAM DURING THE 2008-2020 PERIOD
}

\author{
Hung-Long Tran; Manh-Tung Ho \\ Ritsumeikan Asia Pacific University \\ Верри City, Oita Prefecture, Japan
}

October $3^{\text {rd }}, 2021$

In recent decades, climate change has triggered a sequence of extreme weather events and natural hazards around the world (Pham et al., 2020; Shah, 2020; Vuong, 2021). The onslaught of natural disasters has devastated agricultural production, and thus, pose an imminent threat to developing countries, as these nations are heavily relied on agriculture. According to World Bank (2020), agriculture accounts for more than a quarter of GDP in many developing countries, and the livelihoods of 65 percent of poor working adults around the world are attached to agricultural activities. It is high time to address the risk of climate change to mitigate the consequences toward agricultural production, and to do that, it is necessary to raise the awareness of every individual on the importance of the problem.

Therefore, researchers worldwide have been studying people's perceptions regarding climate variations. Abid et al. (2019) found out that external factors, such as education, collaboration, geographical location, etc., complement internal determinants to form the perceptions of local farmers in Pakistan about climate change. In addition, age and gender are also deciding factors to comprehend how farmers in the Himalayas perceive the changes in climate (Sharma et al., 2020). Poortinga et al. (2019) further affirm the significance of political aspects in acknowledging European families' viewpoints of climate variations. In Vietnam, as being one of the world's largest agricultural countries, awareness of climate change has been extensively explored recently, focusing on the two areas of the Mekong River Delta and the 
northern mountainous area (Hak et al., 2016; Pham et al., 2020; Ngo et al., 2019; Pham et al., 2020; Furu and Van, 2013).

For the Mekong River Delta, which accounts for more than a half of Vietnamese staple food crops and fish production (Be et al., 2007). Nevertheless, the site is also one of the most affected areas by climate change and is constantly threatened by environmental problems. According to Hak et al. (2016), among communities in Mekong Delta region, economic factors are the most influenced determinant toward people's perception and awareness of environmental changes. On the one hand, the low-income group is more attentive and knowledgeable to climate variations, and also more conscious about environmental risks, since their works tend to be closely related to agricultural activities. However, they are not well aware of their roles in environmental protection (Hak et al., 2016). On the other hand, the high-income group, even though is undereducated about risks from climate change than low-income residents, is proved to be better at acknowledging their responsibility in protecting the environment (Hak et al., 2016). From these findings, the researchers suggested that the lowincome households should be supplemented with knowledge regarding the connection between environmental conservation and poverty reduction, which would not only improve their incomes but would also facilitate environmental protection behaviors. Meanwhile, the highincome residents need to be educated on the negative consequences of climate change on economic development, thus enhance their knowledge, and subsequently raise their quality of actions on the subject of environmental protection (Hak et al., 2016).

In another study on adaptive responses of farmers in Mekong Delta region, Ngo et al. (2019) suggested that adaptive perceptions, which are the perspectives and interpretations of adaptive measures based on beliefs and understanding, are the most crucial factors in determining farmers' responses to climate change. The adaptive measures the farmers follow stem from their perceptions of natural shocks induced by climate change, and these measures 
have strong connections with their farming practices, such as managing water usage, modifying crop and variety, altering planting methods, and changing the planting schedule (Ngo et al., 2019). These findings highlight the needs to raise the awareness of famers on climate change, as well as improve the infrastructure and credit source to properly conduct the adaptive measures (Ngo et al., 2019).

Next, regarding the northern mountainous area, the communities here heavily rely on agriculture, similar to the livelihood of residents in Mekong River Delta. Nevertheless, the environmental risks they constantly have to deal with are flash floods and landslides, due to the geological structure of the mountainous region (Pham et al., 2020). According to Pham et al. (2020), internal factors, such as agricultural experience, gender, and ethnicity are significantly correlated to the awareness of mountainous households on environmental risks. Farmers who are male, as well as those who have more than a year of experience in agriculture, are more aware of risks from flash floods and landslides. The same applies to those who belong to an ethnic minority, as they are more attached to forest and agricultural activities than the Kinh people (Pham et al., 2020). On the other hand, external factors, i.e., distance to market, climate information, and agri-ecological zone, generally have no impact on farmers' awareness, except the distance to market (Pham et al., 2020). Pham et al. (2020) concluded that households who live within one kilometre of the market gather more information about environmental risks. Overall, different factors influence the awareness of people in different groups, therefore, targeted educational programs need to be provided for specific groups to increase and balance the general understanding of environmental risks in the same region (Pham et al., 2020).

In terms of adaptive capability, Pham et al. (2020) found out that ethnicity, variety of income sources, and organization membership are the three primary determinants of mountainous households' ability to adapt to environmental risks. The majority of people here are minor ethnic people, who are lack education and thus are constrained in accessing 
information from the authorities. Not only that, but their income is also low and not sustainable because of too much reliance on agriculture and forestry (Pham et al., 2020). Last but not least, those who are members of organizations, such as the Farmer's Union or Women's Union, are benefited from the increasing connections to the community, as well as the support of necessary information regarding agricultural production and adaptive responses (Pham et al., 2020).

How to raise awareness of farmers about climate change is also a vital topic in the literature. Farmers may be aware of changes to their health, but then they fail to associate those changes with the variations of climate (Furu and Van, 2013). The low level of awareness among people, especially people of rural households, is probably the biggest constraint in improving sustainability awareness in Vietnam. This seems to be a common problem among developing countries, as according to a survey of Lee et al. (2015), just 65 percent of the respondents in developing nations in Asia or Africa have heard of climate change and its impacts, contrasting to the figure of 90 percent of respondents in Europe or North America. Therefore, most importantly, the government should establish educational programs for farmers, not only aiming to increase their educational level, but also targeting to enhance their knowledge about climate change and equip them with the ability to deal with climate variations (Pham et al., 2020). What's more, directions and instructions regarding emergency situations should be disseminated to every household (Hak et al., 2016). Besides, the authority should also support the households financially, so that the farmers can have a fund to obtain the necessary equipment in dealing with environmental risks, such as upgrading the irrigation system to flexibly manage water in both dry and wet seasons (Pham et al., 2020; Pham \& Vuong, 2009). Combating climate change in Vietnam is a pressing issue and raising the people's awareness of environmental risks should be the very first important measure that needs to be taken as soon as possible. Here, it is vital to understand the cultural nuances of Vietnamese people when dealing with future risks (Vuong et al., 2018, 2020). 
On a side note, the literature on climate change awareness in Vietnam is mainly focused on communities residing in highly affected places by climate change, such as the Mekong Delta river and the northern mountainous region. However, there is a lack of articles concerning the less-affected areas, including the Red River Delta or the urban areas. In addition, the level of awareness of the fishermen living off the sea is not documented, although the livelihood of this group of people will be strongly fluctuated due to climate change. These are the gaps within the literature and Vietnamese researchers should consider covering in future research studies (Vuong, 2018; Vuong, 2020).

\section{References:}

Abid, M., Scheffran, J., Schneider, U. A., \& Elahi, E. (2019). Farmer perceptions of climate change, observed trends and adaptation of agriculture in Pakistan. Environmental Management, 63, 110-123. https://doi.org/10.1007/s00267-018-1113-7

Be, T. T., Sinh, B. T., \& Miller, F. (2007). Challenges to sustainable development in the Mekong delta: Regional and national policy issues and research needs. The sustainable Mekong research network (Sumernet), Bangkok, Thailand, pp. 11-12.

Furu P., \& Van D. K. (2013) Health Impacts of Climate and Environmental Change: Awareness and Challenges to Adaptation. In: Bruun O., Casse T. (eds) On the Frontiers of Climate and Environmental Change. Environmental Science and Engineering (Environmental Engineering). Springer, Berlin, Heidelberg. https://doi.org/10.1007/978-3-642-35804-3_11

Hak, D., Nadaoka, K., \& Vo, P. (2016). Socioeconomic Conditions and Perceptions of Environmental Risks in the Mekong Delta, Vietnam. Coastal Management, 44, 1-21. 10.1080/08920753.2016.1233796. 
Lee, T., Markowitz, E., Howe, P., Ko, C.-Y., \& Leiserowitz, A. (2015). Predictors of public climate change awareness and risk perception around the world. Nature Climate Change, 5, 1014-1020. https://doi.org/10.1038/nclimate2728

Ngo, Q.-T., Nguyen, H.-R., Nguyen, D.-T., Doan, N.-P., Le, V.-T., \& Thai, T.-K. H. (2019). Adaptive Perception and Adaptation Responses to Weather Shocks: An Adaptation Deficit. AGRIS on-line Papers in Economics and Informatics, 11(2), 55-70. ISSN 1804-1930. DOI 10.7160/aol.2019.110206.

Phạm Minh Chính, Vương Quân Hoàng. (2009). Kinh tế Việt Nam: Thăng trầm và đột phá. Nxb Chính trị Quốc gia, Hà Nội.

Pham, T. T. N., Nong, D., \& Garschagen, M. (2020). Natural Hazard's Effect and Farmers' Perception: Perspectives from Flash Floods and Landslides in Remotely Mountainous Regions of Vietnam. Science of The Total Environment, 759. doi:10.1016/j.scitotenv.2020.142656

Pham, T. T. N., Nong, D., Raghavan Sathyan, A., \& Garschagen, M. (2020). Vulnerability Assessment of Households to Flash Floods and Landslides in the Poor Upland Regions of Vietnam. Climate Risk Management, 28. doi:10.1016/j.crm.2020.100215

Poortinga, W., Whitmarsh, L., Steg, L., Böhm, G., \& Fisher, S. (2019). Climate change perceptions and their individual-level determinants: a cross European analysis. Global Environmental Change, 55, 23-35. https://doi.org/10.1016/j.gloenvcha.2019.01.007

Shah, H. (2020). Global problems need social science. Nature, 577(295). https://doi.org/10.1038/d41586-020-00064-x 
Sharma, A., Batish, D. R., Uniyal, S. K. (2020). Documentation and validation of climate change perception of an ethnic community of the western Himalaya. Environmental Monitoring and Assessment, 192. https://doi.org/10.1007/s10661-020-08512-x

Vuong, Q. H. (2020). Reform retractions to make them more transparent. Nature, 582, 149. https://doi.org/10.1038/d41586-020-01694-X

Vuong, Q. H. (2021). The semiconducting principle of monetary and environmental values exchange. Economics and Business Letters, 10(3), 284-290.

10.17811/ebl.10.3.2021.284-290.

Vuong, Q.H. (2018). The (ir)rational consideration of the cost of science in transition economies. Nature Human Behaviour, 2(1), 5-5. doi:10.1038/s41562-017-0281-4

Vuong, Q.-H., Bui, Q.-K., La, V.-P., et al. (2018). Cultural additivity: behavioural insights from the interaction of Confucianism, Buddhism and Taoism in folktales. Palgrave Communications, 4(1), 143.

Vuong, Q.-H., Ho, M.-T., Nguyen, H.-K. T., et al. (2020). On how religions could accidentally incite lies and violence: folktales as a cultural transmitter. Palgrave Communications, 6(1), 82.

World Bank. (2020). Agriculture and Food: Overview. https://www.worldbank.org/en/topic/agriculture/overview 